\title{
Unsur Kemuliaan dalam Syariat Pengharaman; Reinterpretasi Kata "Haram" dalam Al-Qur'an Melalui Metode Isytiqaq
}

\author{
Oleh: Salman Al Farisi \\ Salman.alfarisi66@gmail.com
}

\begin{abstract}
Abstrak: Selama ini kata haram dimaknai sebagai sesuatu yang harus dihindari, dijauhi, dan dilarang yang bisa berdampak pada hukuman dosa. Pemahaman seperti ini melupakan suatu elemen penting dalam makna internal dari kata "haram" dengan memperhatikan asal kata dan derivasinya dalam alQur'an, yakni adanya unsur penghormatan dan kemuliaan. Metode yang dilakukan dalam penelitian ini ialah pendekatan kebahasaan melalui metode isytiqaq. Hasil yang didapat dalam penelitian ini ialah elemen kemuliaan yang terlupakan tersebut merupakan faktor fundamental dimana aturan itu muncul sebagai bentuk penjagaan atas kemuliaan yang sudah ditetapkan oleh Allah selama ini, bukan hanya sebagai pengekang yang membatasi kebebasan manusia.
\end{abstract}

Kata kunci: Isytiqaq, Makna internal kata, Kemuliaan

\section{A. Pendahuluan}

Menurut Ibn Araby, manusia diciptakan oleh Allah sebagai tempat Tajally (penampakan/manifestasi) Tuhan yang paling sempurna; ia merupakan alam kecil (mikrokosmos) yang tercermin padanya alam besar (makrokosmos); dan tergambar padanya sifat-sifat ke-Tuhanan. Oleh sebab itu manusia diangkat sebagai Khalifah di bumi. ${ }^{1}$ Demikianlah manusia disebut sebagai al-insan, yang konteksnya selalu menampilkannya sebagai makhluk yang istimewa secara fisik, mental, dan kecerdasan, yang berbeda dengan makhluk lain. ${ }^{2}$

Proses penciptakan manusia di dunia kemudian diarahkan oleh-Nya melalui beberapa aturan dalam syariat-Nya. Syariat Allah mengajak kepada penalaran yang akan menggiring ke arah pengetahuan kebenaran, ${ }^{3}$ penalaran ini dilakukan oleh akal dengan mengetahui hal-hal yang seharusnya dilakukan dan 
tidak. $^{4}$ Aturan-aturan Allah tersebut terbentuk dalam syariat kewajiban dan pelarangan (pengharaman) serta pilihan manusia dalam melakukan sesuatu. ${ }^{5}$ Karenanya, agama dalam bahasa Latin disebut dengan religio yang berakar dengan kata kerja religare yang berarti "mengikat kembali", maksudnya, dengan berreligi ialah seseorang mengikat dirinya kepada Tuhannya. ${ }^{6}$ Hakikat pengikatan diri disini bukan berarti membatasi gerak manusia, akan tetapi adanya kemashlahatan berupa pemeliharaan. $^{7}$

Kata haram dalam istilah Fiqih ialah sesuatu atau perkara yang dilarang oleh Syara', yang berdosa jika mengerjakannya dan berpahala jika meninggalkannya, dan sebagai lawan dari halal. ${ }^{8}$ Menurut para ushuliyyin, haram didefinisikan dengan sesuatu ketetapan yang harus ditinggalkan. Kata "haram" bersinonim dengan kata "al-mahdzur (المحظور/yang dilarang)", yakni sesuatu yang mengancam pelakunya dan memuji orang yang meninggalkannya.9" Dalam Ushul Fiqih, istilah "haram" merupakan salah satu jenis dari hukum taklifi yang didefinisikan sebagai ketentuan Allah untuk meninggalkan suatu tindakan secara tegas, berbanding terbalik dengan istilah wajib, dimana ia sebagai ketentuan Allah untuk mengerjakan suatu tindakan secara tegas. ${ }^{10}$ Dari sinilah, haram menjadi lawan dari wajib dalam bidang Ushul Fiqih.

Perkara yang diharamkan dalam syariat Islam ada dua macam; Pertama, haram karena dzatnya, seperti darah, bangkai, dan lain sebagainya. Kedua, haram karena ada unsur lainnya, yaitu yang membuat perkara yang asalnya mubah menjadi haram, seperti dalam bentuk pakaian, harta benda, tempat tinggal, makanan dan minuman, dan lain sebagainya. Jenis kedua tersebut menjadi haram disebabkan dua hal; Pertama, mengambilnya dengan cara yang tidak baik (bukan hak milik), seperti mencuri, berkhianat, dan sebagainya. Kedua,mengambil tanpa adanya izin Allah, meskipun pemiliknya mengizinkan, seperti riba, berjudi dan sebagainya. ${ }^{11}$ Apabila Allah mengharamkan sesuatu, maka diharamkan pula segala sesuatu yang mengantarkan kepadanya.

Selama ini pemaknaan kata haram lebih kepada bidang penetapan hukum Islam, padahal jika melihat kembali penggunaan kebahasaannya dalam al-Qur'an, baik derivasi 
maupun penggunaan tema, maka ditemukan adanya makna internal yang terlupakan dalam kata haram tersebut. Salah satu kajian kebahasaan berupa derivari, morfologi dan penggunaannya ialah ilmu Isytiqaq.

\section{B. Isytiqaq; Sebuah Metode Asal-Usul Kosa Kata Arab}

Kata Isytiqaq (اشتقاق) diambil dari kata شقّ- يشق (syaqqayasyaqqu) yang bermakna membelah, meretakkan, memecahkan. Dalam kamus munawwir, isytiqaq ialah pengasalan kata, sedangkan ilmu isytiqaq ialah ilmu etimologi, ${ }^{12}$ ada juga yang menyebutnya sebagai ilmu derivasi. ${ }^{13}$ Secara terminologi, Jalaluddin al-Suyuti mengutip pendapat dalam Syarh al-Tashîl yang mengatakan bahwa isytiqaq ialah mengambil sighat dari bentuk yang lain dengan disertai adanya kesamaan dari sudut makna, materi asal dan posisi susunannya, untuk menunjukkan bahwa makna yang kedua ada pada makna asal (pertama) dengan tambahan yang berguna. ${ }^{14}$ Lebih ringkas lagi, Tammām Hassān menyatakan bahwa isytiqaq ialah katakata yang mempunyai bentuk yang berbeda, tetapi mempunyai keterkaitan dalam tiga hurufnya ( $f a^{\prime}$ fi'il, 'ain fi' $i l$, dan lam $\left.f i^{\prime}{ }^{\prime} l\right)^{15}$. M. Quraish Shihab mendefinisikan al-isytiqaq yakni proses pembentukan kata yang menghasilkan leksem baru (derivasi).

Untuk memberikan pemahaman yang lebih, penulis memberikan satu contoh yaitu derivasi kosa kata yang huruf asalnya terdiri dari $k a f$-ta'-ba', yang nantinya dalam isytiqaq sughra menghimpun makna umum berupa "tulisan" (الكتابة).

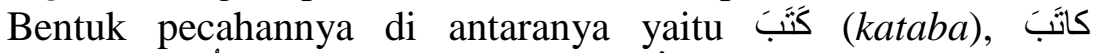

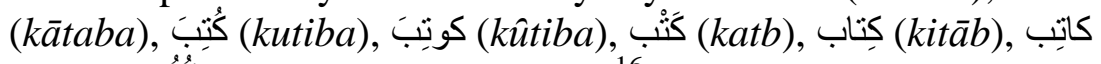
(kâtib), كُنَّ (kutub), dan sebagainya.

Makna dan lafadz ialah sesuatu yang tidak bisa dipisahkan. Lafadz adalah apa yang diucapkan, baik terdengar maupun tertulis. Sedangkan makna ialah kandungan dan tujuan atas suatu lafadz. Salah satu hal terpenting dalam menetapkan makna adalah pengetahuan tentang al-Isytiqaq, yakni asal usul kata. Karena hal ini sangat menentukan makna suatu lafadz ${ }^{17}$ sekaligus untuk menghidari kekeliruan dalam menentukan makna. Karena ada beberapa kasus kekeliruan dalam menetapkan asal usul suatu kosa kata. Rujuklah ke Mukaddimah 
dalam kitab Mu'jam Mufahras li Alfadz al-Qur'an karya Fuad abd al-Baqî, Di sana dia menunjukkan sekian banyak kekeliruhan yang terdapat dalam Nujum al-Furqan fi Atraf alQur'an karya orientalis Jerman, Guztav Leberecht Flügel (18021870). ${ }^{18}$

Menurut Ibn Faris, dalam Bahasa Arab terdapat qiyas ${ }^{19}$, di mana kata asal bisa mengembangkan kosa kata-kosa kata baru, proses pengembangan kata ini disebut dengan isytiqaq (pemecahan). Seperti kosa kata Jin merupakan bentuk pecahan (musytaq) dari Ijtinan, Jannah, dan lain-lain. Kosa kata yang terdiri atas huruf jim dan nun menunjukkan atas makna tertutup $($ al-sitr $) .^{20}$

\section{Kata Haram, Derivasi dan Penggunaan Temanya dalam al-Qur'an}

Berbeda dengan penjelasan ulama Ushul Fiqih, dalam Lisan al-'Arab, Kata harām (حرام) merupakan lawan dari kata halal. Sedangkan kata haruma (حَرُمَ) bermakna menghormati atau memuliakan. ${ }^{21}$ Menurut Ibnu Faris, semua kata yang berasal dari $\underline{h} a^{\prime}$-ra'-mim mengandung makna larangan (المنع) dan penegasan (التشديد). Seperti contoh kata orang i hram (إحرام) yaitu orang yang sedang melakukan rangkaian ibadah haji atau umrah yang ditandai dengan memakai pakaian tertentu pada miqat. Disebut demikian karena adanya larangan melakukan hal-hal yang dibolehkan di luar ihram seperti berburu dan menggauli istri. Bulan haram (الثهر الحرام) ialah bulan dilarangnya berperang. Selanjutnya jika melakukan haji, orang Arab melepaskan pakaiannya dan tidak memakainya ketika berada di tanah suci, pakaian itu dinamakan harim (حريم)

Kata haram dengan segala pecahannya terdapat 83 kali di dalam al-Qur'an. Dengan bentuk fi'il madhi (حرّم), baik yang ma'lum maupun yang majhul sebanyak 34 kali, bentuk fi'il mudhari' sebanyak lima kali, bentuk masdar haraman (حرما) sebanyak dua kali dan haramān (حر اما) sebanyak 26 kali, bentuk jamak hurum (حرم) sebanyak lima kali dan hurumat (حر) (حرمات) sebanyak dua kali, bentuk isim maf'ul mahrum (محرم) (محروم) sebanyak empat kali dan muharram (محرّم) sebanyak lima kali. ${ }^{23}$

Dalam penggunaanya maknanya, penulis meringkasnya dalam tabel dibawah ini: ${ }^{24}$ 
106 | Salman Al Farisi: Unsur Kemuliaan dalam Syariat Pengharaman......

\begin{tabular}{|c|c|c|c|}
\hline No. & Bentuk & $\begin{array}{l}\text { Penggunaan } \\
\text { tema }\end{array}$ & Keterangan \\
\hline \multirow[t]{4}{*}{01} & \multirow[t]{4}{*}{$\begin{array}{c}\text { Fiil Madhi } \\
\text { baik yang } \\
\text { ma'lum } \\
\text { maupun } \\
\text { yang } \\
\text { majhul } \\
\text { (حرّم) }\end{array}$} & Makanan & $\begin{array}{l}\text { Pengharaman } \\
\text { mengonsumsi bangkai, } \\
\text { darah, daging babi, } \\
\text { binatang yang disembelih } \\
\text { bukan karena Allah. } \\
\text { seperti dalam QS. 2:173 } \\
\text { dan QS. 16:115 } \\
\text { Pengharaman } \\
\text { mengonsumsi binatang } \\
\text { yang tercekik, yang } \\
\text { dipukul, yang jatuh, yang } \\
\text { diterkam hewan buas } \\
\text { sampai mati. Seperti } \\
\text { dalam QS. 5:3 rezeki } \\
\text { Mengharamkan } \\
\text { yang telah dihalalkan oleh } \\
\text { Allah. seperti dalam QS. } \\
\text { 6:140 }\end{array}$ \\
\hline & & Wanita mahram & $\begin{array}{l}\text { Wanita yang haram untuk } \\
\text { dinikahi, yang tertera } \\
\text { dalam QS. } 4: 23\end{array}$ \\
\hline & & $\begin{array}{c}\text { Beberapa } \\
\text { perbuatan yang } \\
\text { diharamkan }\end{array}$ & $\begin{array}{l}\text { Riba. Seperti dalam QS. } \\
2: 275 \\
\text { Menikah dengan orang } \\
\text { musyrik. Seperti dalam } \\
\text { QS. 24;3 } \\
\text { Menyekutukan Allah, } \\
\text { durhaka kepada orang tua, } \\
\text { membunuh anak karena } \\
\text { khawatir miskin, } \\
\text { melakukan -perbuatan } \\
\text { keji, dan membunuh } \\
\text { orang tidak secara hak. } \\
\text { Seperti dalam QS. 6: 151 } \\
\text { dan QS. 17: 33 }\end{array}$ \\
\hline & & Mekkah & Yang disucikan oleh \\
\hline
\end{tabular}


Salman Al Farisi: Unsur Kemuliaan dalam Syariat Pengharaman......| 107

\begin{tabular}{|c|c|c|c|}
\hline & & & $\begin{array}{l}\text { Allah. seperti dalam QS. } \\
\text { 27: } 91\end{array}$ \\
\hline & & $\begin{array}{l}\text { Larangan yang } \\
\text { bersifat } \\
\text { menundukkan } \\
\text { (taskhir ilahi) }\end{array}$ & $\begin{array}{lr}\text { Pengharaman } & \text { Musa } \\
\text { menyusu } & \text { kepada } \\
\text { perempuan lain } & \text { selain } \\
\text { ibunya. QS. 28: 12 } & \end{array}$ \\
\hline & & $\begin{array}{l}\text { Larangan yang } \\
\text { bersifat paksaan }\end{array}$ & $\begin{array}{l}\text { Pengharaman surga dan } \\
\text { kenikmatannya } \\
\text { orang-orang kafir dan } \\
\text { musyrik. Seperti dalam } \\
\text { QS. 5: 72 dan QS. 7: } 50\end{array}$ \\
\hline 02 & $\begin{array}{c}\text { Fiil } \\
\text { Mudhari' }\end{array}$ & $\begin{array}{c}\text { Hal yang } \\
\text { diharamkan dan } \\
\text { yang dihalalkan } \\
\text { oleh Allah }\end{array}$ & $\begin{array}{l}\text { Peringatan agar tidak } \\
\text { mengharamkan apa yang } \\
\text { dihalakan-Nya. Seperti } \\
\text { dalam QS. 5: 87, QS. 7: } \\
\text { 157, QS. 9: 29, dan QS. } \\
\text { 66: }\end{array}$ \\
\hline & & $\begin{array}{c}\text { Bulan-bulan } \\
\text { haram }\end{array}$ & $\begin{array}{l}\text { Kecaman perbuatan orang } \\
\text { kafir yang tidak konsisten } \\
\text { (mengundur-undurkan) } \\
\text { terhadap bulan-bulan } \\
\text { haram. Yang terdapat } \\
\text { pada QS. 9: } 37\end{array}$ \\
\hline 03 & $\begin{array}{l}\text { Isim } \\
\text { Masdar } \\
\text { حرما }\end{array}$ & Tanah Mekkah & $\begin{array}{lcr}\text { Sebutan } & \text { dari } & \text { tanah } \\
\text { Mekkah. } & \text { Yang } & \text { terdapat } \\
\text { dalam QS. 28: } 57 & \text { dan QS. } \\
\text { 29: } 67 & \end{array}$ \\
\hline 04 & $\begin{array}{c}\text { Isim } \\
\text { Masdar } \\
\text { حر ام }\end{array}$ & Tanah Mekkah & $\begin{array}{l}\text { Dengan rangkaian kata al- } \\
\text { Masjidil Haram yang } \\
\text { Mengacu pada makna } \\
\text { arah kiblat atau tempat } \\
\text { dengan makna yang lebih } \\
\text { luas, yakni termasuk di } \\
\text { dalamnya daerah-daerah } \\
\text { sekitarnya. Seperti dalam } \\
\text { QS. 2: 144, 149. 150, 191, } \\
\text { 196, 217 dan QS. 5: } 2 \\
\text { Dengan rangkaian kata al- }\end{array}$ \\
\hline
\end{tabular}


108 | Salman Al Farisi: Unsur Kemuliaan dalam Syariat Pengharaman......

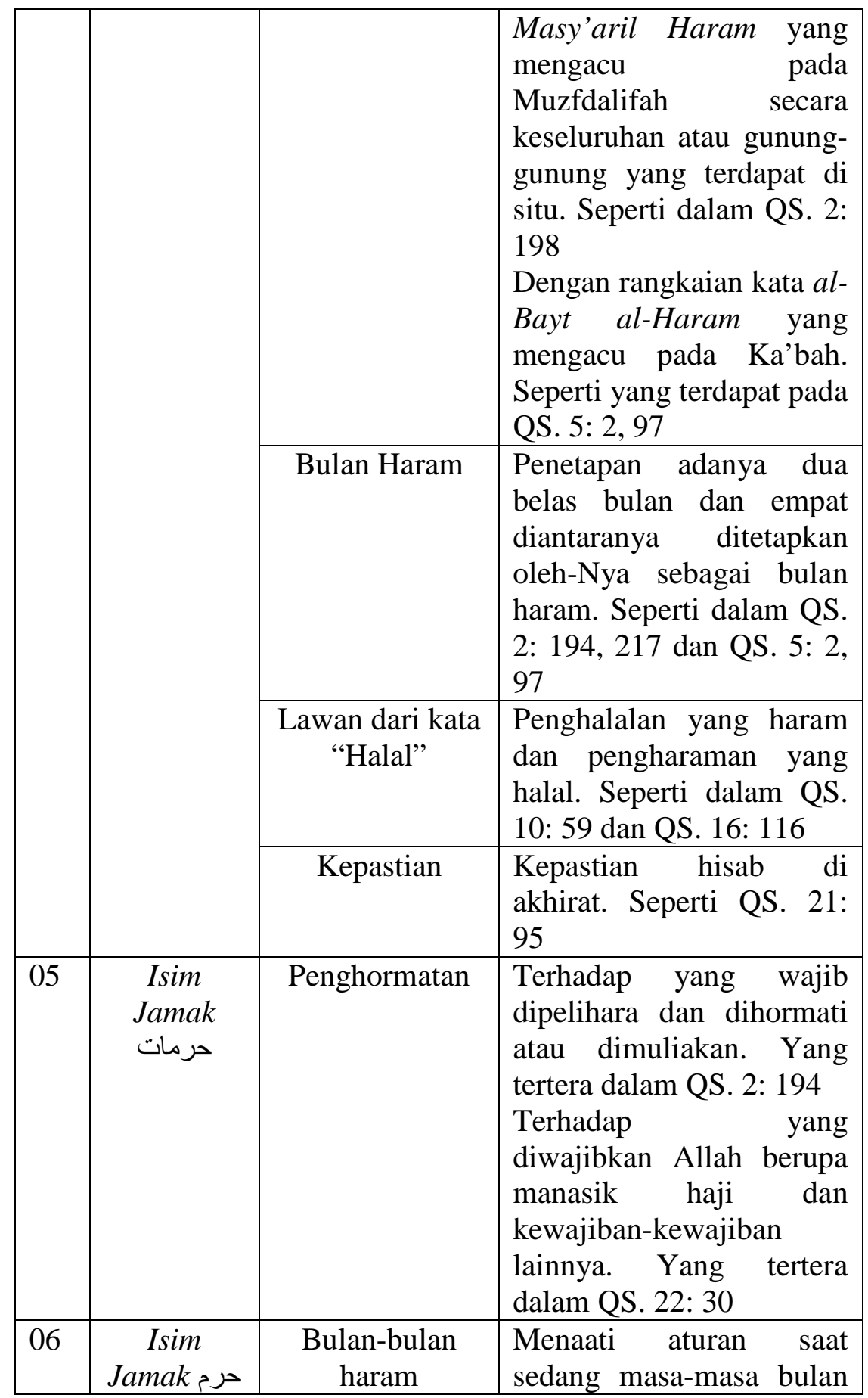




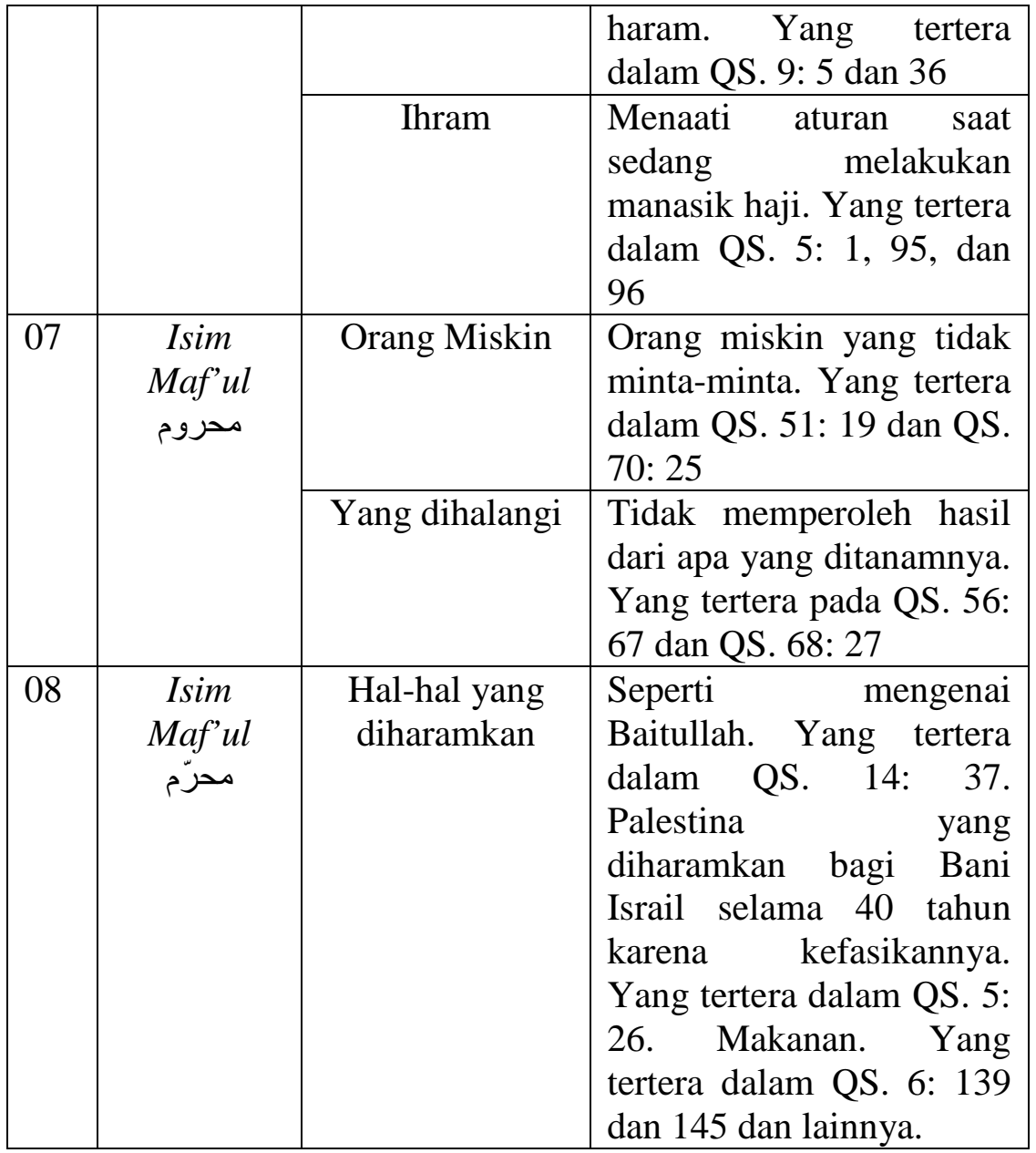

\section{Kemuliaan sebagai Makna Dasar dari Haram}

Al-Raghib al-Ashfahani dalam kitabnya Mufradat Alfadz. al-Qur'an, mencari beberapa kemungkinan kenapa larangan itu timbul. Apakah karena Tuhan yang mencegahnya yang disebut dengan taskhîr ilahi (تسخير إلهي), seperti yang terdapat dalam QS. Al-Qashash [28]: 12. Allah mengharamkan atau mencegah Musa menyusu pada wanita lain selain ibunya. Ataukah karena sudah menjadi ketentuan Allah seperti yang terdapat di dalam QS. Al-Maidah [5]: 72. Allah mengharamkan surga bagi orangorang musyrik. Dan juga larangan itu didasarkan atas 
pertimbangan akal atau didasarkan pada syariat atau larangan itu timbul dari orang yang dijunjung perintahnya. ${ }^{25}$

Jika dilihat lagi dari kebahasaan, Menurut M. Quraish Shihab, kata haram (حرام) dari segi bahasa pada mulanya berarti mulia atau terhormat seperti Masjid al-Haram. ${ }^{26}$ Karenanya, dari asal kata yang sama tersebut memunculkan derivasi yang berupa hurmat (حرمة) yang bermakna hormat, hingga dalam bahasa Indonesia sudah tak asing lagi dengan kosa kata "hormat" sebagai bentuk memuliakan dan menghargai sesuatu. ${ }^{27}$ Sesuatu yang mulia atau terhormat melahirkan aneka ketentuan yang menghalangi dan melarang pihak lain melanggarnya. Dari sini, kata haram diartikan sebagai melarang, mencegah, menghalangi dan menghindari. ${ }^{28}$

Allah swt. telah menciptakan manusia, memuliakannya, dan mempersiapkan untuknya segala yang dibutuhkan berupa makanan dan minuman, menghalalkan banyak hal, mengharamkan banyak hal, memerintah dan melarang banyak hal, sebagai bentuk rahmat dan kebaikan kepadanya serta penjagaan untuknya. Segala bentuk penyembahan, ketaatan pada-Nya memiliki unsur kemaslahatan dan manfaat bagi manusia itu sendiri, serta menghindar dari kemudharatan dan kerusakan. ${ }^{29}$ Syariat pengharaman Allah untuk manusia bersifat sebagai bentuk penjagaan dan perlindungan bagi mereka, kecuali ketentuan Allah atas pengharaman bagi orang-orang Yahudi terhadap makanan yang sebelumnya dihalalkan untuk mereka sebagai bentuk hukuman atas kejahatan yang mereka lakukan. $^{30}$

\section{E. Unsur Kemuliaan yang Ditetapkan dalam Syari'at-Nya}

Setelah teridentifikasi beberapa derivasi dan penggunaan tema kata haram dalam al-Qur'an serta penyebutan unsur kemuliaan sebagai makna dasar dari kata haram. Berikut penulis akan menjabarkan objek apa saja yang dimuliakan oleh Allah terkait syariat yang berbicara perihal pengharaman.

A. Makkah; Tanah Haram, Masjid al-Haram, dan Bayt alHaram, dan Haramain

Penggunaan kata haram dengan Makkah sebagai konteksnya, dipahami oleh banyak ahli bahasa sebagai tanah, daerah atau masjid yang mulia nan suci yang dihormati. 
Dinamakan demikian karena di sini terdapat tapal batas yang melingkari Makkah. Dengan pembatas ini, orang kafi ${ }^{1} \mathrm{r}$ tidak diperkenankan memasuki kawasan ini. ${ }^{31}$ Kota Makkah dan Madinah dijuluki sebagai Haramain, karena kedua kota tersebut dimuliakan oleh Allah. dimaknai sebagai kaum yang memasuki tanah haram. ${ }^{33}$

Selain dijuluki sebagai tanah haram, ia juga dijuluki sebagai al-Mukarramah, karena ia merupakan kota yang dimuliakan oleh Allah, sebab di sinilah Allah memerintahkan Nabi Ibrahim dan Ismail untuk mendirikan Bayt Allah (Ka'bah). Ia juga dijuluki Haramun Amin (QS. Al-Qashash [28]: 57), juga dijuluki sebagai Ummu al-Qura, karena ia merupakan kota tertua di dunia.Namun, dari berbagai julukan, nama yang paling terkenal ialah Makkah, yang berarti "mendesak", yakni mendesak orang-orang yang maksiat kepada Allah untuk keluar dari kawasan itu. ${ }^{34}$

Berbagai keutamaan yang dimiliki kota Makkah tidak terlepas dari sejumlah tempat dan situs yang ada di sana, diantaranya ialah Makkah merupakan tempat yang Allah pilih sebagai Baitullah, tempat kelahiran Nabi Muhammad dan sebagai pusat arah ibadah hamba-hamba-Nya, serta mewajibkan orang muslim (bagi yang mampu) untuk datang ke tempat tersebut baik dari jarak jauh maupun dekat untuk melaksanakan ibadah haji. Selain itu di sanalah Adam dan Hawa dipertemukan, tempat pertama kali al-Qur'an diturunkan, serta adanya sumur Zamzam yang ada sejak zaman Nabi Ismail. ${ }^{35}$

Dalam hadis disebutkan bahwa Rasulullah bersabda pada saat penaklukan kota Makkah, "Sesungguhnya negeri ini telah Allah haramkan pada saat diciptakan langit dan bumi. Maka, dia haram dengan keharaman Allah hingga hari kiamat. Tidak boleh dicabut durinya, tidak boleh diusir binatang buruannya, tidak boleh diambil barang temuannya kecuali ia bermaksud untuk mengumumkannya, dan tidak boleh dipotong rumputnya.",36

Bentuk kemulian kota Makkah juga merupakan hasil doa dari Nabi Ibrahim sebagaimana dalam QS. Al-Baqarah [2]: 126 
112 | Salman Al Farisi: Unsur Kemuliaan dalam Syariat Pengharaman......

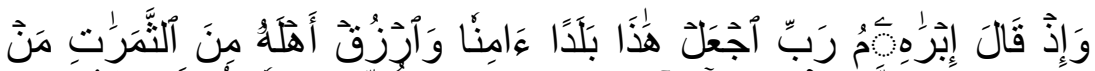

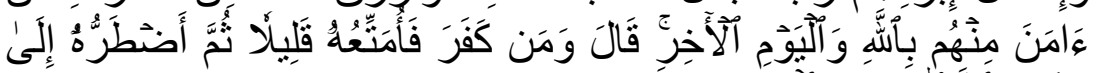

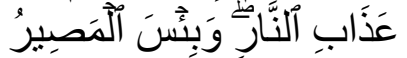
"Dan (ingatlah), ketika Ibrahim berdoa: "Ya Tuhanku, jadikanlah negeri ini (Makkah), negeri yang aman sentosa, dan berikanlah rezeki dari buah-buahan kepada penduduknya yang beriman diantara mereka kepada Allah dan hari kemudian. Allah berfirman: "Dan kepada orang yang kafirpun Aku beri kesenangan sementara, kemudian Aku paksa ia menjalani siksa neraka dan itulah seburuk-buruk tempat kembali"

Begitu pula doa Nabi Muhammad atas kota Madinah, sebagaimana dalam Hadis yang berbunyi:

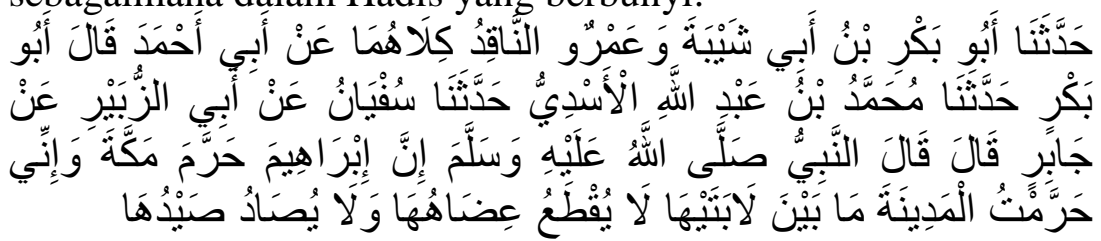

"Telah menceritakan kepada kami Abu Bakr bin Abu Syaibah dan Amru An Naqid keduanya dari Abu Ahmad - Abu Bakr berkata- Telah menceritakan kepada kami Muhammad bin Abdullah Al Asadi telah menceritakan kepada kami Sufyan dari Abu Zubair dari Jabir ia berkata; Nabi shallallahu 'alaihi wasallam bersabda: "Nabi Ibrahim telah mengharamkan kota Makkah, dan aku pun menjadikan kota Madinah sebagai tanah haram. Yaitu di antara kedua bukitnya yang berbatu-batu hitam itu. karena itu, pepohonannya tidak boleh ditebang, dan hewan buruannya juga tidak boleh diburu."

B. Bulan Muharram dan Empat Bulan Haram

Kata Muharram secara bahasa ialah yang diharamkan atau yang dimuliakan. Muharram adalah nama bulan pertama tahun Hijriah. Dinamakan demikian karena bulan tersebut dimuliakan oleh orang Arab Jahiliyyah dan diharamkan dalam bulan tersebut perbuatan saling membunuh atau berperang. ${ }^{38}$ Muharram disebut sebagai Syahrullah (Bulannya Allah), dinamakan demikian karena tidak diperbolehkan (diharamkan) adanya peperangan dan penganiayaan pada waktu itu. ${ }^{39}$ Muharram merupakan empat bulan haram selain bulan Rajab, 
Dzulqa'dah dan Dzulhijjah. Sebagaimana dalam QS. AtTaubah: 36

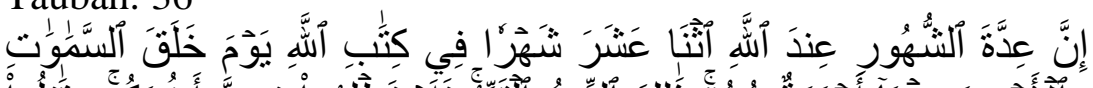

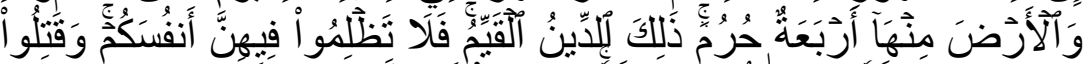

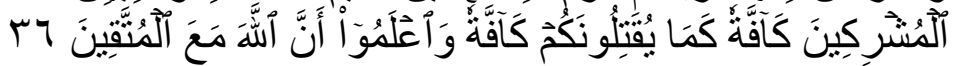

"Sesungguhnya bilangan bulan pada sisi Allah adalah dua belas bulan, dalam ketetapan Allah di waktu Dia menciptakan langit dan bumi, di antaranya empat bulan haram. Itulah (ketetapan) agama yang lurus, maka janganlah kamu menganiaya diri kamu dalam bulan yang empat itu, dan perangilah kaum musyrikin itu semuanya sebagaimana merekapun memerangi kamu semuanya, dan ketahuilah bahwasanya Allah beserta orang-orang yang bertakwa”

Bulan Muharram menyimpan peristiwa besar serta tanda kekuasaan Allah, salah satu peristiwa besar tersebut ialah ketika Allah menyelamatkan Nabi Musa beserta kaumnya dari Firaun dan bala tentaranya. ${ }^{40}$ Sebagaimana diriwayatkan dalam hadits: ${ }^{41}$

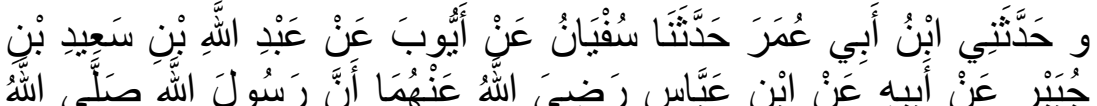

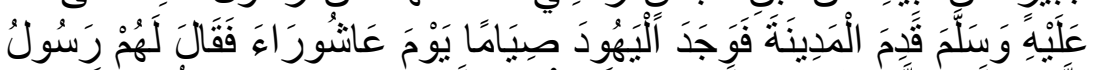

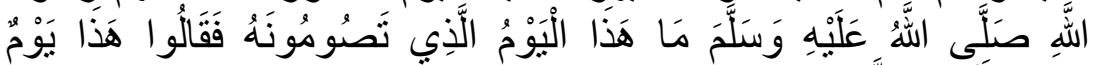

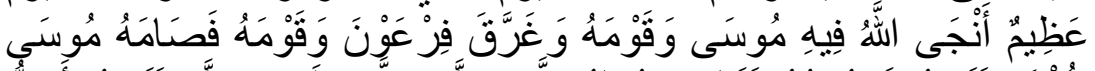

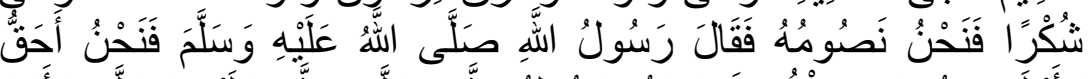

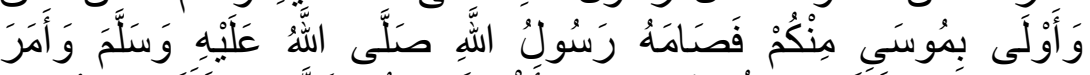

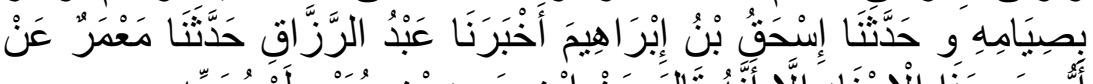

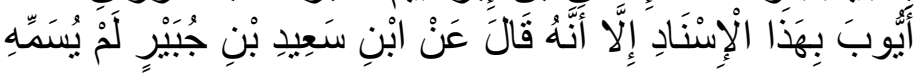

"Dan telah menceritakan kepadaku Ibnu Abu Umar telah menceritakan kepada kami Sufyan dari Ayyub dari Abdullah bin Sa'id bin Jubair dari bapaknya dari Ibnu Abbas radliallahu 'anhuma, bahwa Rasulullah shallallahu 'alaihi wasallam mendatangi kota Madinah, lalu didapatinya orang-orang Yahudi berpuasa di hari 'Asyura. Maka beliau pun bertanya kepada mereka: "Hari apakah ini, hingga kalian berpuasa?" mereka menjawab, "Hari ini adalah hari yang agung, hari ketika Allah memenangkan Musa dan Kaumnya, dan menenggelamkan Fir'aun serta kaumnya. Karena itu, Musa 
puasa setiap hari itu untuk menyatakan syukur, maka kami pun melakukannya." Maka Rasulullah shallallahu 'alaihi wasallam bersabda: "Kami lebih berhak dan lebih pantas untuk memuliakan Musa daripada kalian." kemudian beliau pun berpuasa dan memerintahkan kaum puasa di hari itu. Dan Telah menceritakan kepada kami Ishaq bin Ibrahim telah mengabarkan kepada kami Abdurrazaq telah menceritakan kepada kami Ma'mar dari Ayyub dengan isnad ini, hanya saja ia berkata; "Dari Ibnu Sa'id bin Jubair." Ia tidak menyebutkan namanya.

Dalam kitab I'anatut Tālibîn, disebutkan sebuah hadis yang menyatakan bahwasanya hari Asyurah (10 Muharram) adalah hari dimana Allah menerima taubat nabi Adam, maka jadilah beliau orang yang bersih. Dan Allah mengangkat nabi Idris pada hari itu ke tempat atau kedudukan yang tinggi. Dan Allah mengeluarkan nabi Nuh dari kapalnya. Dan Allah menyelamatkan nabi Ibrahim dari kobaran api. Dan Allah menurunkan kitab Taurat kepada nabi Musa. Dan Allah mengeluarkan nabi Yusuf dari penjara. Dan Allah mengembalikan mata penglihatan nabi Ya'qub. Dan Allah membebaskan nabi Ayyub dari bencana (penyakit). Dan Allah mengeluarkan nabi Yunus dari perut ikan. Dan Allah membelah lautan (menjadi daratan) bagi bani Israil. Dan Allah pada hari itu mengampuni dosa nabi Dawud. Dan Allah pada hari itu memberikan kerajaan kepada nabi Sulaiman. Dan Allah pada hari itu mengampuni dosa-dosa nabi Muhammad yang telah lalu maupun yang akan datang. ${ }^{42}$ Akan tetapi hadis yang disebutkan tersebut dianggap maudhu' (palsu) oleh Ibnu al-Jauzi dalam alMaudhu'at-nya.

\section{Ihram dan Harim dalam Ritual Haji}

Kata ihram merupakan bentuk derivasi dari kata haram, yang kemudian menjadi istilah khas dalam rangkaian perjalanan ibadah haji. Menurut syara', ihram adalah niat untuk memulai rangkaian ibadah haji atau umrah. ${ }^{44}$ Ketika seseorang berihram berarti ia telah memasuki ritual haji dan diharamkan atasnya melakukan sejumlah aktifitas yang tidak ada kaitannya dengan ibadah haji. Ihram mengharamkan sesuatu yang sebelumnya halal, yang dalam fiqih istilah ini disebut dengan muharramat 
al-ihram (larangan-larangan dalam ihram). Pelanggaran terhadap larangan tersebut menyebabkan seseorang wajib membayar Dam (fidyah). Larangan-larangan dalam haji (ihram) ada yang khusus untuk pria (seperti dilarang untuk memakai penutup kepala, memakai pakaian yang berjahit, dan memakai sepatu yang menutup mata kakinya), ada yang khusus untuk wanita (seperti larangan menutup muka dan memakai sarung tangan) dan ada pula yang berlaku untuk keduanya (seperti larangan memotong kuku dan rambut, memakai wangi-wangian, berburuh atau membunuh binatang, nikah atau menikahkan orang, bersetubuh dengan istri, mencaci, mengumpat, bertengkar, memotong atau mencabut tumbuhan). Adapun jika melakukannya maka akan dikenai denda. ${ }^{45}$ Kemuliaan ritual haji ini mempunyai kaitan erat dengan kemuliaan di tanah haram.

\section{Wanita Muhrim dan Mahram}

Kata muhrim dan mahram secara bahasa bermakna yang diharamkan. Yaitu wanita yang diharamkan untuk dinikahi karena beberapa hal; pertalian darah (seperti ibu seterusnya ke atas, anak perempuan seterusnya kebawah, saudara perempuan, bibi dan keponakan perempuan), sesusuan (seperti ibu yang menyusui dan saudara sesusuan), perkawinan (seperti mertuam anak tiri, ibu tiri, dan menantu perempuan) dan haram dengan cara mengumpulkan (saudara perempuan dari istri dan saudara perempuan mertua). ${ }^{46}$

Illat mengenai pengharaman tersebut tidak disebutkan, baik secara umum maupun khusus. Akan tetapi banyak ulama yang melakukan istinbath, pikiran, dan perkiraan belaka mengenai alasan tersebut, diantaranya ialah pernikahan sedarah dapat melemahkan keturunan bersamaan dengan perjalanan waktu, karena unsur-unsur kelemahan yang turun-temurun adakalanya berpangkal pada keturunan. Berbeda halnya bila terjadi pencampuran dengan darah baru dari orang lain (yang bukan keturunan sendiri), dengan unsur-unsurnya yang istimewa, sehingga dapatlah diperbaharui kehidupan dan unsurunsur generasinya. Hubungan di antara sebagian tingkat mahram, menurut Sayyid Quthub, adalah hubungan pemeliharaan dan kasih sayang, memuliakan dan menghormati. Selain itu, hubungan pernikahan itu memperluas kawasan 
keluarga dan mengembangkannya dengan dilatarbelakangi ikatan kekerabatan. Karena itu, tidak ada urgensinya pernikahan antara keluarga dekat dengan keluarga dekat, yang dipadukan oleh unsur kekeluargaan yang dekat. Karena itulah, diharamkan menikah dengan mereka karena tidak ada hikmah dan manfaatnya. Juga tidak diperkenankan nikah dengan kerabat kecuali orang yang telah jauh hubungannya, sehingga hampir lepas dari ikatan kekeluargaan. ${ }^{47}$

Semua syari' at sepakat mengharamkan menikahi wanita yang ada hubungan nasab. Agama Yahudi dan Nasrani yang ada sampai sekarang mengharamkan mereka juga, karena timbul dari insting manusia, bahkan sebagian binatang yang tinggi tidak mengambil kasih sayangnya dari sangkarnya sendiri. Berbagai penelitian ilmiah menyimpulkan bahwa pernikahan antara selsel binatang yang berbeda gen keturunan akan menghasilkan anak keturunan yang kuat dan pernikahan antara binatang yang satu gen keturunan menghasilkan keturunan yang lemah. ${ }^{48}$

\section{E. Makanan Haram}

Jenis makanan yang diharamkan dalam al-Qur'an diantaranya ialah darah, daging babi, bangkai, dan sejenisnya. Illat mengenai keharaman tersebut oleh Ali Mustafa Ya'qub dikategorikan kedalam beberapa hal, berupa penilaian baik (thayyibāt-Khabā'is), bahaya (dharar), najis (najasah). ${ }^{49}$ Makanan-makanan haram tersebut berimplikasi terhadap kesehatan manusia. Rasyid Ridha menjelaskan tentang pengharaman bangkai hewan yang mati dengan sendirinya, hal ini disebabkan tidak lain disebabkan oleh penyakit. Lalu darah diharamkan karena ia merupakan tempat yang paling baik untuk pertumbuhan bakteri-bakteri. Babi diharamkan karena ia jorok, baginya makanan yang paling lezat ialah kotoran. Yang diharamkan dari babi yaitu mengkonsumsi dagingnya, salah satu penyebab haramnya yakni adanya cacing yang mematikan dan mempunyai pengaruh psikologis yang jelek terhadap kehormatan bagi orang-orang yang mengonsumsinya. ${ }^{50}$ Menurut al-Maraghi, menurut ketetapan ahli kedokteran kontemporer, cacing yang ada dalam tubuh babi disebabkan karena kotoran yang dikonsumsinya. Salah satu jenis cacing tersebut ialah cacing pita. Selain itu, daging babi merupakan daging yang 
paling susah dicerna karena mengandung banyak lemak yang dapat menghambat kelancaran pencernaan, sehingga perut merasa berat atau gembung dan membuat denyut jantung tidak teratur. $^{51}$

\section{F. Kesimpulan}

Allah menciptakan manusia dalam bentuk dan kondisi yang mulia, dan mengarahkan manusia untuk tetap dalam kemuliaannya. Adanya aturan-aturan Allah dalam syari'atnya, seperti pengharaman terhadap sesuatu hal, mempunyai maslahah tersendiri bagi kehidupan manusia. Kemaslahatan syariat pengharaman tersebut ialah sebuah penjagaan atas suatu kemuliaan yang berupa ketetapan dan aturan-aturanNya. Allah mengharamkan beberapa hal untuk dikonsumsi dan dikerjakan bukan berarti Ia membatasi gerak manusia, tapi lebih menjaga dan menyelamatkan manusia supaya terhindar dari hal-hal yang buruk, baik itu untuk jiwa maupun raga.

1 Abd Qadir Mahmud, al-falsafah al-Sufiyyah fi al-Islam (Dar alFikr al-Araby, tt), h 575.

${ }^{2}$ M.Quraish Shihab, Wawasan al-Qur'an (Bandung; Mizan, 1996), h. 280

${ }^{3}$ Ibn Rusy, Kaitan Filsafat dengan Syariat, terj. oleh Ahmad Shodiq Noor (Jakarta; Pustaka Firdaus, 1993), h. 18

4 Imam Khomeini, Insan Ilahiah; Menjadi Manusia Sempurna dengan Sifat-sifat Ketuhanan, terj. oleh M. Ilyas (Jakarta; Pustaka Zahra, 2004), h. 8

${ }^{5}$ Dalam Ushul Fiqih, hukum Allah yang bersifat demikian disebut sebagai hukum taklifi, yang mempunyai lima macam hukumnya, yakni wajib, sunnah, haram, makruh, dan mubah. Lihat di Abd al-Wahhab al-Khallaf, Ilm Ushul al-Fiqh (Kairo; Maktabah al-Da'wah wa Syabab al-Azhar, 2009), h. 105

6 Dadang Kahmad, Sosiologi Agama (Jakarta; Ghalia Indonesia, 2002), h. 29

7 Ismail Muhammad Syah, dkk., Filsafat Hukum Islam (Jakarta; Bumi Aksara, 1992), h. 65

${ }^{8}$ M. Abdul Mujieb, dkk., Kamus Istilah Fiqih (Jakarta; Pustaka Firdaus, 1995), h. 99

${ }^{9}$ Amir Abd al-Aziz, Ushul al-Fiqh al-Islami, jil. 1 (T.Tp; Dar alSalam, T.Th), h. 66

${ }^{10}$ Wahbah al-Zuhaili, Ushul Fiqh al-Islamiyah, Jil. 1 (Damaskus; Dar al-Fikr, 1986), h. 45 
11 Muhammad ibn Ibrahim at-Tuwaijiri, Ensiklopedi Manajemen Hati; Fikih Tauhid-Fikih Syariah, diterj. oleh Suratman dan Agus Makmun, Jil. 1 (Jakarta; Darus Sunah, 2014), h. 383

12 Ahmad Warson Munawwir, Al-Munawwir; Kamus ArabIndonesia (Surabaya; Pustaka Progresif, 1997), h. 732

13 Hans Wehr, A Dictionary of Modern Written Arabic (Beirut; Maktabah Lubnān, 1974), h. 487. Derivasi ialah istilah dalam ilmu linguistik mengenai pengimbuhan afiks yang tidak bersifat inflektif pada bentuk kata dasar untuk membentuk kata. Lihat di Tim Penyusun Kamus, Kamus Besar Bahasa Indonesia, Edisi ketiga (Jakarta; Balai Pustaka, 2007), h. 256

${ }^{14}$ Jalaluddîn al-Suyûtî, Al-Muzhîr fi 'Ulum al-Lughah wa Anwa'iha, jil. 1 (Kairo; Maktabah Dar al-Turast, T. Th), h. 346

15 Tammām Hassān, al-Lughah al-'Arabiyyah Ma'nāha wa Mabnāha (Kairo; al-Hay’ah al- 'Ammah, 1979), h. 166

${ }^{16}$ Abd al-Maqșud Muhammad Abd al-Maqsud, Mafhum al-Isytiqāq al-Sarfì wa Tatawwurihi, (Kairo; Maktabah al-Tsaqafah al-Diniyah, 2006), h. 92

${ }^{17}$ M. Quraish Shihab, Kaidah Tafsir; Syarat, Ketentuan, dan Aturan yang Patut Anda Ketahui dalam Memahami al-Qur'an (Ciputat; Lentera Hati, 2013), h. 77

${ }^{18}$ Muhammad Fuad Abd al-Baqî, Al-Mu'jam al-Mufahras li Alfadz al-Qur'an al-Karim (Kairo; Dar al-Hadis, 2007), h. III

19 Qiyas dalam bidang linguitik ialah metode penciptaan bahasa baru. Untuk lebih jelasnya lihat Utsman ibn Jinnî, Al-Khas ais jil. 1 (Kairo; alMaktabah al-Ilmiyyah, T. Th), h. 97

${ }^{20}$ Ahmad ibn Faris, al-Sahabî fi Fiqh al-Lughah al-'Arabiyah wa Masa'iliha, jil. 1 (Beirut; Dar al-Kutub al-Ilmiyah, 1997) h. 35

${ }^{21}$ Ibn Manzur, Lisan al- 'Arab (Kairo; Dar al-Ma'arif, 1119), h. 844

${ }^{22}$ Ahmad ibn Faris, Mu'jam Maqayis al-Lughah, jil. 2 (T.Tp; Dar al-Fikr, 1979), h. 45

${ }^{23}$ Muhammad Fuad Abd al-Baqî, Al-Mu'jam al-Mufahras li Alfadz al-Qur'an al-Karim, h. 242

${ }^{24}$ Tim Lentera Hati, Ensiklopedi al-Qur'an; Kajian Kosa Kata, jil. 1 (Ciputat; Lentera Hati, 2007), h. 290

25 Al-Raghib al-Ashfahani, Mufradat Alfadz al-Qur'an (Damaskus; Dar al-Qalam, 2015), h. 229

26 M. Quraish Shihab, Tafsir al-Misbah; Pesan, Kesan, dan Keserasian al-Qur'an, Jil. 14 (Ciputat; Lentera Hati, 2011), h. 166

27 Tim Penyusun Kamus Pusat Bahasa, Kamus Besar Bahasa Indonesia, ed. 3 (Jakarta; Balai Pustaka, 2007), h. 408

${ }^{28}$ M. Quraish Shihab, Tafsir al-Misbah, Jil. 14, h. 167

29 Muhammad ibn Ibrahim at-Tuwaijiri, Ensiklopedi Manajemen Hati, diterj. oleh Suratman dan Agus Makmun, Jil. 1, h. 383-386 
${ }^{30}$ Lihat QS. An-Nisa':160-161 dalam Jalaluddîn al-Suyûtî, Dur alMantsur fi al-Tafsir bi al-Ma'tsur, jil. 5 (Kairo; Markaz li al-Buhuts wa alDirasat al-'Arabiyah wa al-Islamiyah, 2003), h. 127

31 Syahruddin El Fikri, Sejarah Ibadah; Menelusuri Asal-Usul, Memantapkan Penghambaan (Jakarta; Republika, 2014), h. 258-259

32 Muhammad Rawwas Qal'ahji, Al-Mausu'ah al-Fiqhiyyahn alMuyassar, jil. 1 (Kuwait; Dar al-Nafais, T.Th), h. 741

${ }^{33}$ Ibn Manzur, Lisan al-'Arab (), h. 845

${ }^{34}$ Syahruddin El Fikri, Sejarah Ibadah, h. 259

${ }^{35}$ Syahruddin El Fikri, Sejarah Ibadah, h. 258

${ }^{36}$ Muslim ibn al-Hajjaj, Shahih Muslim (Kairo; Dar al-Hadis, 2010),

h. 420

${ }^{37}$ Muslim ibn al-Hajjaj, Shahih Muslim, h. 423

${ }^{38}$ M. Abdul Mujieb, dkk., Kamus Istilah Fiqih, h. 216

${ }^{39}$ Ibn Manzur, Lisan al-'Arab (), h. 845

${ }^{40}$ Muhammad bin Shalih Al Utsaimin, Dhiya' al-Lami' min Khutab al-Jawami', (T.Tp, T.Th), h. 381

${ }^{41}$ Muslim ibn al-Hajjaj, Shahih Muslim , h. 343

${ }^{42}$ Abu Bakar bin Muhammad Syatho ad-Dimyati, I'anatut Tāilibîn, jil. 2 (T.Tp; Dar Ihya' al-Kutub al-Arabiyah, T.Th), h. 267

${ }^{43}$ Ibnu al-Jauzi, Kitab al-Maudhu'at min al-Ahadits al-Marfu'at, jil. 2 (Beirut; Adwa'u al-Salaf, 1997), h. 571

${ }^{44}$ Wahbah az-Zuhaili, Fiqh al-Islam wa Adillatuh, jil. 3 (Damaskus; Dar al-Fikr, 1989), h. 121

4545 Denda tersebut bisa berupa menyembelih seekor kambing, berpuasa 10 hari; 3 hari ketika masih menjalankan ibadah haji dan 7 hari setelah berada di rumah, atau bersedekah 3 sha' kepada fakir-miskin. Lihat M. Abdul Mujieb, dkk., Kamus Istilah Fiqih, h. 217

${ }^{46}$ M. Abdul Mujieb, dkk., Kamus Istilah Fiqih, h. 186 dan 218

47 Sayyid Quthub, Fî Zilâlil Qur'an, Terj. As'ad Yasin, dkk. (Jakarta: Gema Insani, 2011), h. 312

48 Abdul Aziz Muhammad Azzam dan Abdul Wahhab Sayyed Hawwas, Fiqh Munakahat Khitbah, Nikah dan Talak (Jakarta: Amzah, 2009), h. 140-141

${ }^{49}$ Ali Mustafa Ya'qub, Kriteria Halal-Haram untuk Pangan, Obat, dan Kosmetika Menurut Al-Qur'an dan Hadis, Terj. Mahfud Hidayat (Jakarta; Pustaka Firdaus, 2013), h. xii

50 Rasyid Ridha, Tafsir al-Manar, jil. 6 (Mesir; Maktabah alQahirah, 1380 H), h. 135-136

51 Al-Maraghi, Tafsir al-Maraghi, jil. 6 (Mesir; Mustafa al-Babil Halabi, 1974), h. 48 


\section{REFRENSI}

ad-Dimyati, Abu Bakar bin Muhammad Syatho. I'anatut Tālibîn, jil. 2, T.Tp; Dar Ihya' al-Kutub al-Arabiyah, T.Th.

Al Utsaimin, Muhammad bin Shalih. Dhiya' al-Lami' min Khutab al-Jawami', T.Tp, T.Th.

al-Ashfahani, Al-Raghib. Mufradat Alfadz al-Qur'an,

Damaskus; Dar al-Qalam, 2015.

al-Aziz, Amir Abd. Ushul al-Fiqh al-Islami, jil. 1, T.Tp; Dar al-

Salam, T.Th.

al-Baqî, Muhammad Fuad Abd. Al-Mu'jam al-Mufahras li

Alfadz al-Qur'an al-Karim, Kairo; Dar al-Hadis, 2007.

al-Hajjaj, Muslim ibn. Shahih Muslim, Kairo; Dar al-Hadis, 2010.

al-Jauzi, Ibnu. Kitab al-Maudhu'at min al-Ahadits al-Marfu'at,

jil. 2, Beirut; Adwa'u al-Salaf, 1997.

al-Khallaf, Abd al-Wahhab. Ilm Ushul al-Fiqh, Kairo;

Maktabah al-Da'wah wa Syabab al-Azhar, 2009.

al-Maqsud, Abd al-Maqsud Muhammad Abd. Mafhum alIsytiqāq al-Sarfì wa Tatawwurihi, Kairo; Maktabah alTsaqafah al-Diniyah, 2006.

Al-Maraghi, Tafsir al-Maraghi, jil. 6, Mesir; Mustafa al-Babil Halabi, 1974.

al-Suyûtî, Jalaluddîn. Al-Muzhîr fi 'Ulum al-Lughah wa Anwa'iha, jil. 1, Kairo; Maktabah Dar al-Turast, T. Th al-Suyûtî, Jalaluddîn. Dur al-Mantsur fi al-Tafsir bi al-Ma'tsur,

jil. 5, Kairo; Markaz li al-Buhuts wa al-Dirasat al'Arabiyah wa al-Islamiyah, 2003.

al-Zuhaili, Wahbah. Ushul Fiqh al-Islamiyah, Jil. 1, Damaskus; Dar al-Fikr, 1986.

at-Tuwaijiri, Muhammad ibn Ibrahim. Ensiklopedi Manajemen

Hati; Fikih Tauhid-Fikih Syariah, diterj. oleh Suratman dan Agus Makmun, Jil. 1, Jakarta; Darus Sunah, 2014.

Azzam, Abdul Aziz Muhammad dan Hawwas, Abdul Wahhab Sayyed. Fiqh Munakahat Khitbah, Nikah dan Talak, Jakarta: Amzah, 2009. 
az-Zuhaili, Wahbah. Fiqh al-Islam wa Adillatuh, jil. 3, Damaskus; Dar al-Fikr, 1989.

El Fikri, Syahruddin. Sejarah Ibadah; Menelusuri Asal-Usul, Memantapkan Penghambaan, Jakarta; Republika, 2014

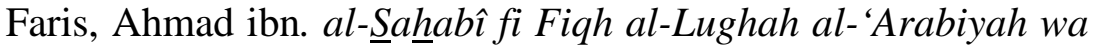
Masa'iliha, jil. 1, Beirut; Dar al-Kutub al-Ilmiyah, 1997.

Faris, Ahmad ibn. Mu'jam Maqayis al-Lughah, jil. 2, T.Tp; Dar al-Fikr, 1979.

Hassān, Tammām. al-Lughah al-'Arabiyyah Ma'nāha wa Mabnāha. Kairo; al-Hay'ah al-'Ammah, 1979.

ibn Jinnî, Utsman. Al-Khasais jil. 1, Kairo; al-Maktabah alIlmiyyah, T. Th.

Kahmad, Dadang. Sosiologi Agama, Jakarta; Ghalia Indonesia, 2002.

Khomeini, Imam. Insan Ilahiah; Menjadi Manusia Sempurna dengan Sifat-sifat Ketuhanan, terj. oleh M. Ilyas Jakarta; Pustaka Zahra, 2004.

Mahmud, Abd Qadir. al-falsafah al-Sufiyyah fi al-Islam, Dar alFikr al-Araby, tt.

Manzur, Ibn. Lisan al- 'Arab, Kairo; Dar al-Ma' arif, 1119 H.

Mujieb, M. Abdul. dkk., Kamus Istilah Fiqih, Jakarta; Pustaka Firdaus, 1995.

Munawwir, Ahmad Warson. Al-Munawwir; Kamus ArabIndonesia, Surabaya; Pustaka Progresif, 1997.

Qal'ahji, Muhammad Rawwas. Al-Mausu'ah al-Fiqhiyyahn alMuyassar, jil. 1, Kuwait; Dar al-Nafais, T.Th.

Quthub, Sayyid. Fî Zilâlil Qur'an, Terj. As'ad Yasin, dkk. Jakarta: Gema Insani, 2011.

Ridha, Rasyid. Tafsir al-Manar, jil. 6, Mesir; Maktabah alQahirah, $1380 \mathrm{H}$.

Rusyd, Ibn. Kaitan Filsafat dengan Syariat, terj. oleh Ahmad Shodiq Noor, Jakarta; Pustaka Firdaus, 1993.

Shihab, M. Quraish. Kaidah Tafsir; Syarat, Ketentuan, dan Aturan yang Patut Anda Ketahui dalam Memahami alQur'an, Ciputat; Lentera Hati, 2013.

Shihab, M. Quraish. Tafsir al-Misbah; Pesan, Kesan, dan Keserasian al-Qur'an, Jil. 14, Ciputat; Lentera Hati, 2011. 
Shihab, M. Quraish. Wawasan al-Qur'an, Bandung; Mizan, 1996.

Syah, Ismail Muhammad. dkk., Filsafat Hukum Islam, Jakarta; Bumi Aksara, 1992.

Tim Lentera Hati, Ensiklopedi al-Qur'an; Kajian Kosa Kata, jil. 1, Ciputat; Lentera Hati, 2007.

Tim Penyusun Kamus Pusat Bahasa, Kamus Besar Bahasa Indonesia, ed. 3, Jakarta; Balai Pustaka, 2007.

Wehr, Hans. A Dictionary of Modern Written Arabic, Beirut; Maktabah Lubnān, 1974.

Ya'qub, Ali Mustafa. Kriteria Halal-Haram untuk Pangan, Obat, dan Kosmetika Menurut Al-Qur'an dan Hadis, Terj. Mahfud Hidayat, Jakarta; Pustaka Firdaus, 2013. 